\title{
Kemampuan Reproduksi Induk dan Pertumbuhan Anak Kambing Peranakan Etawah, Gembrong, dan Kosta
}

\author{
A. Destomo, M. Syawal, \& A. Batubara \\ Loka Penelitian Kambing Potong, Badan Litbang Pertanian \\ PO BOX 1 Galang, Deli Serdang, Sumatera Utara, Indonesia 20585 \\ Email: alfiandestomo@gmail.com \\ (Diterima : 03 September 2019 ; Disetujui : 07 Januari 2020)
}

\begin{abstract}
Indonesia has various types of local goat germplasm like a goat Peranakan Etawah (PE), Gembrong, and Kosta. Information of those local goats including the parent reproduction and kids productivity are still limited. Study aims to evaluate maternal reproduction capability and kids productivity of goat PE, Gembrong, and Kosta. Study was conducted in 24 does and 44 kids of PE, Gembrong, and Kosta in Loka Kambing Potong (Goat Research Station), Sumatera Utara. A goat mated with of the study from each the goat breed. Data of reproduction were collected from mating to calving. Data of kids productivity were collected from birth to nine month-old. As reproductive capability data, the highest litter size and type of birth were demonstrated in goat PE. Goat gembrong produced more male, whereas goat Kosta had shorter pregnant duration than other goats. Birth weight of PE was significantly different $(p<0,05)$ to Gembrong and Kosta. Weaning weight was different $(p<0,05)$ between PE and Kosta goat. In addition, daily gain of 6-months, 9-months weight, pre-weaning and postweaning showed no significant differences $(P>0.05)$. Pre-weaning and post-weaning mortality was highest in Kosta.
\end{abstract}

Keywords: Goat, peranakan etawah, gembrong, kosta, productivity

\section{PENDAHULUAN}

Plasma nutfah kambing lokal memiliki peranan penting dalam menjaga kekayaan hayati alam Indonesia. Terdapat beberapa jenis plasma nutfah kambing lokal, diantaranya adalah kambing Peranakan Etawah (PE), kambing Gembrong, kambing Kosta, kambing Muara, kambing Marica, kambing Samosir, dan kambing Benggala (Batubara et al., 2014). Masing-masing jenis kambing lokal memiliki keunggulan seperti kambing PE yang mampu memproduksi daging dan susu sama baiknya (Kostaman dan Sutama, 2006), kambing Gembrong yang memiliki keunikan berupa rambut halus dan panjang yang menutupi tubuh hingga muka, dan kambing Kosta yang merupakan kambing asli dari wilayah DKI Jakarta dan Banten. Kambing Kosta berpotensi dalam pemenuhan kebutuhan daging kambing di kawasan ibu kota (Batubara et al., 2014). Plasma nutfah kambing yang ada di Indonesia dapat dijadikan materi pengembangan ternak kambing dengan tujuan tertentu.

Kondisi plasma nutfah kambing di masyarakat saat ini belum dikelola dengan baik. Budidaya kambing dengan kawin silang antar jenis kambing secara bebas dan tidak terkontrol dapat mengancam populasi kambing lokal Indonesia. Kondisi ini ditandai dengan semakin menurunnya populasi kambing Gembrong (Putri dan Dewantari, 2017) dan Kosta (Rusdiana dan Sutedi, 2016) yang statusnya kritis mendekati kepunahan. Diperlukan upaya yang tepat untuk menambah populasi dan kemampuan berproduksi kambing yang ada saat ini dengan berdasarkan data-data yang mendukung. Hingga saat ini masih belum banyak data terbaru tentang plasma nutfah kambing yang dapat digunakan sebagai landasan untuk menentukan upaya melestarikan kambing lokal Indonesia.

Pengembangan kambing lokal di Indonesia dipengaruhi banyak faktor. Menurut Pamungkas (2008) produktivitas anak kambing Kosta dipengaruhi oleh umur induk dan produktivitasnya. Bobot induk pada saat dikawinkan memegang peranan pada produktivitas kambing PE (Kostaman dan Sutama, 2006). Kambing Gembrong mempunyai dimensi ukuran tubuh diantara kambing PE dan kambing Kacang (Suyasa et al., 2016). Usaha yang dilakukan untuk meningkatkan produktivitas kambing lokal 
antara lain dengan mengawinkan kambing lokal dengan kambing yang memiliki produktivitas tinggi (Nurgiartiningsih, 2011), seperti kambing PE dengan kambing Boer (Kostaman dan Sutama, 2005; Nasich, 2011; Kaunang et al., 2014; Sulastri et al., 2014) dan kambing Kacang dengan kambing Boer (Ginting dan Mahmilia, 2008). Selain melalui perkawinan perbaikan produktifitas dapat dilakukan juga seleksi (Bandiati dan Prajoga, 2007; Rasminati, 2013) dan pada estrus beberapa kambing dikawinkan (Setiadi et al., 1997). Kemampuan reproduksi kambing lokal diperbaiki dengan metode perkawinan yang berbeda (Setiadi et al., 1997), seleksi (Yunanda et al., 2013), memperpendek selang beranak, meningkatan jumlah anak sekelahiran, bobot lahir, dan meningkatkan kemampuan hidup anak (Sutama, 2011). Akan tetapi usaha yang dilakukan untuk meningkatkan kemampuan reproduksi dan produktivitas kambing hanya dilakukan pada jenis kambing tertentu saja, yakni kambing PE dan kambing Kacang. Usaha yang sama perlu dilakukan pada kambing lokal yang lain.

Kambing Gembrong dan Kosta saat ini dalam kondisi kritis dan terancam punah serta sudah tidak murni lagi (Putri dan Dewantari, 2017), (Rusdiana dan Sutedi, 2016). Usaha yang tepat untuk mengembangkan dan memurnikan kembali kambing lokal tersebut perlu dilakukan. Pada saat ini data yang dijadikan informasi dasar untuk mengembangkan kambing lokal masih terbatas. Penelitian ini bertujuan untuk mengetahui kemampuan reproduksi induk kambing dan pertumbuhan anak kambing Gembrong dan Kosta. Hasil penelitian ini dapat dijadikan informasi dasar untuk pengembangan dan peningkatan kualitas kambing lokal di Indonesia.

\section{MATERI DAN METODE}

\section{Lokasi dan Waktu Penelitian}

Penelitian ini dilaksanakan mulai bulan Januari 2017 hingga Agustus 2018 di Loka Penelitian Kambing Potong, Kecamatan Galang, Kabupaten Deli Serdang, Sumatera Utara, Indonesia.

\section{Pemeliharaan Hewan Percobaan}

Hewan percobaan yang digunakan merupakan kambing lokal koleksi plasma nutfah yang dikembangbiakkan dan dipelihara di kandang percobaan Loka Penelitian Kambing Potong. Bobot badan induk kambing antara 20-42 kg dengan umur 1,5-4 tahun. Pemeliharaan induk kambing dilakukan dengan cara dikandangkan bersama anak yang belum disapih sehingga anak kambing dapat disusui oleh induknya. Anak kambing disapih pada umur 3 bulan. Setelah disapih anak dipisahkan dari induknya dan dipelihara pada kandang yang berbeda berdasarkan jenis kelamin. Pakan yang diberikan pada induk dan anak lepas sapih adalah pakan hijauan berupa rumput dan legum pada pagi dan sore hari. Pakan konsentrat diberikan pada pagi hari dan dibedakan formulasinya antara induk kambing dengan kambing lepas sapih. Konsentrat diproduksi dari pabrik pakan mini Loka Penelitian Kambing Potong dengan bahan dasar pelepah sawit, bungkil inti sawit, solid decanter, dan tetes tebu. Pakan hijauan diberikan sebanyak $20 \%$ dari bobot badan dengan rata-rata 5-8 g/ekor/hari, pakan konsentrat anak lepas sapih diberikan sebanyak $100 \mathrm{~g} /$ ekor/hari dan konsentrat untuk induk diberikan sebanyak $300 \mathrm{~g} /$ ekor/hari.

\section{Pengamatan Kemampuan Reproduksi Induk}

Hewan ternak yang diamati kemampuan reproduksi pada penelitian ini adalah 7 ekor induk kambing PE, 9 ekor induk kambing Kosta, dan 8 ekor induk kambing Gembrong. Tiap jenis kambing betina dikawinkan dengan pejantan dari jenis kambing yang sama. Penimbangan induk dilakukan pada saat kawin dan saat melahirkan menggunakan timbangan gantung (merek Shelter) berkapasitas $100 \mathrm{~kg}$. Data tanggal kawin, bobot induk kawin, tanggal beranak, bobot beranak, jumlah anak sekelahiran, dan jenis kelamin anak dicatat pada buku data ternak dan didokumentasikan. 


\section{Pengamatan Produktivitas dan Mortalitas} Anak Kambing

Anak kambing yang diamati adalah sebanyak 13 anak kambing PE, 20 ekor anak kambing Kosta, dan 11 ekor anak kambing Gembrong. Anak lahir ditimbang menggunakan timbangan duduk kapasitas $10 \mathrm{~kg}$ (merek Five Goats) setelah dibersihkan oleh induknya sebelum disusui. Anak kambing ditimbang setiap bulan hingga umur 9 bulan. Bobot lahir anak, bobot badan anak setiap bulan dan tanggal kematian anak dicatat dalam buku penimbangan ternak dan didokumentasikan. Pertambahan Bobot Badan Harian (PBBH) didapat dengan membagi pertambahan bobot badan bulanan dengan jumlah hari dalam sebulan. Kematian (mortalitas) anak dihitung dengan persentase jumlah anak yang mati. Persentase kematian ternak dihitung dengan persamaan matematika:

$$
\text { Persentase Kematian }=\frac{x x}{y y} \times 100 \%
$$

Dimana $x=$ jumlah ternak yang mati dan $y$ = jumlah ternak yang lahir atau ternak yang disapih.

\section{Analisis data}

Seluruh data penelitian ditabulasi dan dirata-ratakan dan selanjutnya dianalisis menggunakan ANOVA. Apabila terdapat perbedaan yang nyata dilakukan uji lanjut dengan Uji Jarak Berganda Duncan dengan taraf kepercayaan 5\%. Data diolah menggunakan Program SAS 9.1 (SAS Institute Inc.).

\section{HASIL DAN PEMBAHASAN}

\section{Kemampuan Reproduksi Induk}

Jumlah anak lahir jantan pada kambing PE dan kambing Gembrong lebih banyak dibandingkan kelahiran betina sedangkan kambing Kosta memiliki jumlah kelahiran betina lebih banyak (Tabel 1). Peluang anak lahir jantan dengan lahir betina mempunyai peluang sama besar, akan tetapi pada proses pembuahan dan perkembangannya terjadi pergeseran (Prasojo et al., 2010). Banyak faktor yang memengaruhi rasio jenis kelamin menurut Demiral et al. (2007) diantaranya jumlah anak sekelahiran (litter size), umur induk, berapa kali induk beranak (parity), fertilitas induk, nutrisi, produksi susu induk, tingkat stress induk, lingkungan kandang, musim kelahiran, waktu kawin, jenis perkawinan dan tingkat inbreeding. Pada penelitian ini terdapat induk kambing kosta yang baru beranak satu kali. Diduga hal ini yang memengaruhi jumlah anak betina yang lebih banyak. Jumlah anak kambing lahir jantan lebih banyak sangat menguntungkan pada budidaya kambing pedaging, sedangkan kelahiran anak bentina dimanfaatkan untuk perbanyakan populasi.

Tabel 1. Data rasio jantan-betina, tipe lahir, dan litter size kambing PE, Gembrong, dan Kosta

\begin{tabular}{lccc}
\hline \multicolumn{1}{c}{ Peubah } & PE & $\begin{array}{c}\text { Jenis Kambing } \\
\text { Gembrong }\end{array}$ & Kosta \\
\hline $\begin{array}{l}\text { Rasio Jantan-Betina } \\
\text { Jantan }\end{array}$ & $60,0 \%$ & $63,6 \%$ & $48,3 \%$ \\
$\quad$ Betina & $40,0 \%$ & $36,4 \%$ & $51,7 \%$ \\
Rasio Tipe Lahir Anak & & & \\
Tungal & $40,0 \%$ & $50,0 \%$ & $61.9 \%$ \\
Kembar 2 & $60,0 \%$ & $50,0 \%$ & $33,3 \%$ \\
Kembar 3 & $0 \%$ & $0 \%$ & $4,8 \%$ \\
Litter Size & 1,6 & 1,5 & 1,4 \\
\hline
\end{tabular}

Pada penelitian ini didapatkan anak lahir kembar lebih banyak pada induk kambing PE, sedangkan kambing Kosta lebih banyak anak lahir tunggal (Tabel 1). Rasio ini berpengaruh dengan litter size anak. Semakin banyak anak kembar akan meningkatkan populasi kambing lokal. Kambing PE memiliki litter size yang paling tinggi dan kambing Kosta paling rendah. Menurut Haldar et al. (2014) jumlah anak sekelahiran 
dipengaruhi oleh umur ternak, litter size pada kelahiran sebelumnya, paritas induk, dan bobot badan induk saat kawin dan bunting. Pada penelitian ini induk kambing Kosta terdapat induk yang baru pertama kali beranak dan rataan bobot induk melahirkan rendah. Kondisi ini diduga menjadi penyebab jumlah anak lahir kembar yang rendah, sehingga berpengaruh terhadap litter size.

Tabel 2. Data kemampuan lama bunting dan bobot melahirkan induk kambing PE, Gembrong, dan Kosta

\begin{tabular}{llll}
\hline Peubah & PE & Gembrong & Kosta \\
\hline Lama Bunting (Hari) & $148,11 \pm 3,06^{\mathrm{a}}$ & $150,75 \pm 4,7^{\mathrm{a}}$ & $147,6 \pm 4,27^{\mathrm{a}}$ \\
Bobot melahirkan $(\mathrm{kg})$ & $42,47 \pm 2,45^{\mathrm{a}}$ & $32,60 \pm 7,39^{\mathrm{b}}$ & $27,73 \pm 7,48^{\mathrm{b}}$
\end{tabular}

Catatan: Huruf superskrip yang berbeda pada satu baris menunjukkan perbedaan yang nyata $(\mathrm{P}<0,05)$

Bobot induk melahirkan berbeda nyata $(\mathrm{P}<0,05)$ antara kambing $\mathrm{PE}$ dengan kambing Gembrong dan Kosta yang mencapai $9,87 \mathrm{~kg}$ dan $14,54 \mathrm{~kg}$. Perbedaan bobot badan induk ini disebabkan oleh faktor genetik (Kostaman dan Sutama, 2005). Dalam tulisan Batubara et al. (2014) dinyatakan bahwa ukuran tubuh kambing PE lebih besar dari kambing lokal lain termasuk Gembrong dan Kosta. Sumardianto et al. (2013) mengelompokkan kambing PE sebagai kambing lokal bertipe besar. Bobot badan kambing PE pada penelitian ini lebih tinggi $7,86 \mathrm{~kg}$ dibandingkan penelitian Kostaman dan Sutama (2006), tetapi lebih rendah dari kambing PE yang digunakan dalam penelitian Yulistiani et al. (1999) dengan perlakuan kadar protein berbeda dengan selisih perbedaan antara 5,3-6,32 kg. Perbedaan bobot melahirkan pada kambing PE dengan beberapa hasil penelitian terdahulu disebabkan perbedaan manajemen pakan, umur dan paritas. Mahmalia et al. (2010) menyatakan bahwa kambing yang telah beranak lebih dari satu kali akan memiliki ukuran tubuh lebih besar.

\section{Produktivitas Anak}

Bobot lahir kambing PE $(\mathrm{P}<0,05)$ lebih tinggi dibandingkan kambing Gembrong dan Kosta. Perbedaan bobot lahir dipengaruhi oleh bobot badan induk kambing PE yang secara umum lebih besar dibandingkan kambing Gembrong dan kambing Kosta. Menurut Suyana et al. (Suyasa et al., 2016) rataan bobot induk kambing $\mathrm{PE}$ adalah $36,6 \mathrm{~kg}$, sedangkan bobot induk kambing Gembrong 27,6 kg dan badan kambing Kosta 23,44 kg (Pamungkas, 2008). Menurut Kostaman dan Sutama (2006) peningkatan bobot induk berpengaruh terhadap bobot lahir anak. Kambing yang berasal dari keturunan jenis kambing dengan ukuran besar akan memiliki bobot lahir yang lebih besar yang disebabkan oleh faktor genetis (Kostaman danSutama, 2005). Pada penelitian ini bobot lahir kambing PE lebih rendah dari penelitian Sutama et al. (1999) yakni 3,2-3,9 $\mathrm{kg}$, bobot lahir kambing Gembrong lebih tinggi dari penelitian Mahmalia et al. (2004) 1,5-2 kg dan bobot lahir kambing Kosta tidak jauh berbeda dengan penelitian Mahmalia et al. (2004) yakni 1,45-1,9 kg dan lebih tinggi dari penelitian Pamungkas (2008) 1,62 kg.

Tabel 3. Data produktivitas anak kambing PE, Gembrong, dan Kosta

\begin{tabular}{llll}
\hline \multirow{2}{*}{\multicolumn{1}{c}{ Peubah }} & \multicolumn{3}{c}{ Jenis Kambing } \\
\cline { 2 - 4 } & PE & Gembrong & Kosta \\
\hline Bobot Lahir (kg) & $2,76 \pm 0.55^{\mathrm{a}}$ & $2,07 \pm 0,37^{\mathrm{b}}$ & $1,82 \pm 0,43^{\mathrm{b}}$ \\
Bobot Sapih (kg) & $10,51 \pm 4.5^{\mathrm{a}}$ & $8,9 \pm 2,96^{\mathrm{ab}}$ & $6,18 \pm 1,28^{\mathrm{b}}$ \\
Bobot 6 Bulan (kg) & $12,12 \pm 5.2^{\mathrm{a}}$ & $8,58 \pm 3,84^{\mathrm{a}}$ & $9,66 \pm 1,53^{\mathrm{a}}$ \\
Bobot 9 Bulan (kg) & $15,65 \pm 5.83^{\mathrm{a}}$ & $15,47 \pm 4,83^{\mathrm{a}}$ & $16 \pm 2,89^{\mathrm{a}}$ \\
PBBH Pra Sapih (kg) & $0,085 \pm 0.04^{\mathrm{a}}$ & $0,075 \pm 0,03^{\mathrm{a}}$ & $0,074 \pm 0,04^{\mathrm{a}}$ \\
PBBH Pasca Sapih $(\mathrm{kg})$ & $0,053 \pm 0.08^{\mathrm{a}}$ & $0,01 \pm 0,01^{\mathrm{a}}$ & $0,031 \pm 0,01^{\mathrm{a}}$ \\
\hline
\end{tabular}

Keterangan: Superskrip yang berbeda pada satu baris menunjukkan perbedaan yang nyata $(\mathrm{P}<0,05)$ 
Bobot sapih kambing PE paling tinggi dibandingkan $(\mathrm{P}<0,05)$ kambing Kosta, dan $(\mathrm{P}>0,05)$ kambing Gembrong. Menurut Kosum et al. (2004) bobot sapih dipengaruhi oleh bobot lahir dan tipe kelahiran. Bobot lahir menjadi titik awal produktivitas kambing dalam pertumbuhan. Kambing PE memiliki bobot sapih tinggi dipengaruhi beberapa faktor. Kambing PE merupakan kambing tipe dwiguna sebagai penghasil susu dan daging (Batubara et al., 2014; Ali et al., 2017). Litter size dan kemampuan hidup anak pra sapih memengaruhi bobot sapih terkait kemampuan mengasuh induk dan produksi susu (Snyman et al., 1997). Ditambahkan Hermesch et al. (2000) bahwa selain faktor genetik ternak dan sifat lain juga memengaruhi bobot sapih. Bobot sapih kambing PE pada penelitian ini lebih rendah dibandingkan penelitian Sutama et al. (1999) $10,8-11,0 \mathrm{~kg}$, kambing Gembrong sedikit lebih rendah dari (Mahmalia et al., 2004) yang mencapai 9 kg. Kambing Kosta lebih tinggi dari (Mahmalia et al., 2004) yakni 4,47-5,75 kg dan lebih rendah dari penelitian Pamungkas (2008) yakni 6,9 kg.

Bobot badan kambing umur 6 dan 9 bulan pada ketiga kambing tidak ada perbedaan yang nyata $(\mathrm{P}>0,05)$. Bobot kambing 6 bulan kambing PE lebih rendah dari penelitian (Sutama et al., 1999) yang mencapai 13,6-14,2 kg. Kambing Gembrong memiliki bobot badan 6 bulan lebih rendah dan bobot 9 bulan lebih tinggi dari penelitian Mahmalia et al. (2004) secara berurut 12,4 dan $14,13 \mathrm{~kg}$. Kambing Kosta memiliki bobot badan umur 6 dan 9 bulan lebih tinggi dari penelitian Mahmalia et al. (2004) hanya mencapai 7,1 dan 10,5 kg.

Berdasarkan perbandingan dengan bobot badan kambing dengan umur sama pada penelitian terdahulu, kambing PE pada penelitian ini mempunyai kecenderungan bobot badan lebih rendah. Diduga kambing PE pada penelitian ini mengalami kesulitan beradaptasi terhadap kondisi terputusnya asupan susu dari induk. Pada penelitian Sutama et al. (1999) anak kambing PE yang mempunyai induk dengan produksi susu tinggi mengalami perlambatan pertumbuhan pasca sapih dibandingkan yang memiliki produksi susu lebih rendah. Kondisi ini serupa dengan kambing Kosta dan Gembrong yang kemungkinan mempunyai produksi susu yang lebih rendah, mengingat kambing PE sangat potensial menghasilkan susu. Kambing Kosta yang cenderung mengalami peningkatan bobot badan setelah sapih diduga telah beradaptasi dengan pakan padat lebih awal dibandingkan kambing PE diakibatkan terbatasnya susu induk, sehingga saat disapih kambing Kosta lebih minimal terkena dampak depresi pasca sapih. $\mathrm{PBBH}$ pra sapih ketiga jenis kambing tidak terdapat perbedaan yang signifikan $(\mathrm{P}>0,05)$. Secara genetik kambing PE seharusnya memiliki pertumbuhan yang lebih baik dari kambing Gembrong dan Kosta dikarenakan memiliki produksi susu induk yang tinggi, sebagaimana pendapat Batubara et al. (2014) bahwa kambing PE mempunyai kemampuan produksi susu yang tinggi karena merupakan kambing jenis dwiguna. Akan tetapi apabila ditinjau dari jumlah anak sekelahiran kambing PE yang lebih tinggi dibandingkan kambing Gembrong dan Kosta, faktor ini juga dapat mempengaruhi. Susu yang dihasilkan oleh induk kambing PE dikonsumsi oleh jumlah anak yang lebih banyak dibandingkan kambing Gembrong dan Kosta, sehingga pertumbuhan pra sapih ketiga jenis kambing tidak berbeda nyata. Kondisi yang sama juga terjadi pada penelitian Sutama et al. (1999) dimana kambing yang memiliki produksi susu yang tinggi namun jumlah anak sekelahiran juga tinggi tidak mengalami pertumbuhan yang tidak berbeda dengan induk yang produktifitasnya sedang atau rendah. Faktor lingkungan seperti musim juga berpengaruh terhadap pertumbuhan anak pra sapih. Nasution et al. (2010) menyatakan bahwa pertumbuhan anak pra sapih dipengaruhi oleh musim, pertumbuhan tinggi pada musim hujan dan rendah pada musim kemarau. Pada penelitian ini ketiga jenis kambing dilahirkan pada musim yang sama akibat manajemen pemeliharaan yang menerapkan periode perkawinan yang serentak.

PBBH pasca sapih ketiga jenis kambing tidak berbeda secara signifikan 
$(\mathrm{P}>0,05)$. Pada dasarnya, pertumbuhan kambing pasca sapih lebih dipengaruhi oleh kondisi tubuh dan kondisi lingkungan termasuk pakan. Menurut Mavrogenis et al. (2010) pengaruh musim yang menyebabkan kandungan nutrisi pakan mengalami kenaikan menyebabkan ternak mengalami pertumbuhan yang baik. Pertumbuhan anak kambing cenderung sama karena faktor yang memengaruhi pertumbuhan anak pra sapih sudah berkurang. Aka (2012)juga menyatakan bahwa pada masa pasca sapih, anak kambing sudah tidak tergantung lagi pada konsumsi susu induk, sehingga pertumbuhan cempe tergantung pada pakan yang dikonsumsi. Menurut Sutama et al. (1999) ketergantungan akan susu induk akan berkurang seiring bertambahnya umur kambing. Selanjutnya Mavrogenis et al. (2010) menyatakan pengaruh yang berkaitan dengan kelahiran dan kemampuan memelihara induk hanya berpengaruh hingga masa sapih, selanjutnya dipengaruhi oleh kemampuan individu dan lingkungan.

Tabel 4. Data mortalitas anak kambing PE, Gembrong, dan Kosta

\begin{tabular}{llll}
\hline & \multicolumn{3}{c}{ Jenis Kambing } \\
\hline Peubah & PE & Gembrong & Kosta \\
\hline Mortalitas Pra Sapih (\%) & 13,3 & 9,0 & 33,3 \\
Mortalitas Pasca Sapih (\%) & 12,5 & 30,0 & 35,0 \\
\hline
\end{tabular}

Mortalitas pada anak pra sapih kambing Kosta masih cukup tinggi dibandingkan penelitian Pamungkas (2008) 31,6\% dan (Mahmalia et al., 2004) 21,1\%. Menurut Pamungkas (2008) bobot lahir anak terlalu kecil dan umur induk sudah tua yang berkaitan dengan produksi susu dapat menjadi penyebab tingginya mortalitas pra sapih. Pada praktek pemeliharaanya, induk muda dengan kelahiran pertama memiliki kemampuan mengasuh anak yang masih rendah dapat menyebabkan tingginya mortalitas, karena induk enggan menyusui dan anak kekurangan asupan nutrisi. Selain itu juga faktor teknis seperti kaki anak terjepit di lantai kandang juga dapat menjadi penyebab, karena kambing Kosta tergolong kambing yang kecil dan aktif bergerak.

Mortalitas pasca sapih kambing Gembrong dan Kosta masih tinggi. Dijelaskan Mavrogenis et al. (2010) sebelumnya bahwa kondisi kambing pasca sapih lebih dipengaruhi oleh faktor individu dan faktor lingkungan. Tingginya mortalitas pasca sapih pada kambing Gembrong dan Kosta disebabkan oleh kurangnya kemampuan kambing untuk beradaptasi dengan lingkungan dan pakan setelah sapih. Kambing Gembrong dan Kosta kemungkinan mengalami cekaman akibat terputusnya suplai susu dari induk, selain itu bobot sapih kambing Kosta paling rendah dibandingkan PE.

\section{KESIMPULAN}

Kemampuan reproduksi induk kambing PE lebih tinggi dibandingkan dengan kambing Gembrong dan kambing Kosta pada bobot melahirkan, sedangkan lama bunting tidak berbeda. Bobot lahir kambing PE lebih tinggi dibandingkan dengan kambing Gembrong dan Kosta. Bobot sapih kambing PE lebih tinggi dibandingkan dengan kambing Kosta. Data pertumbuhan lainnya tidak berbeda nyata dengan kecenderungan kambing PE lebih tinggi.

\section{KONFLIK INTERES}

Penulis menyatakan bahwa naskah yang diajukkan tidak terlibat konflik kepentingan yang berhubungan dengan keuangan, pribadi, atau lainnya dengan pihak lain yang terkait dengan materi dalam naskah. Apabila dikemudian hari ditemukan pelanggaran, penulis bersedia untuk dikenakan sangsi sesuai ketentuan yang berlaku.

\section{UCAPAN TERIMA KASIH}

Penulis mengucapkan terima kasih kepada Kepala Loka Penelitian Kambing Potong Dr. Ir. Simon Elieser, M.Si yang telah memberikan izin penggunaan fasilitas dan hewan percobaan milik Loka Penelitian Kambing Potong untuk digunakan dalam 
penelitian. Rekan-rekan peneliti dan administrasi petugas kandang plasma nutfah yang telah membantu terlaksananya penelitian ini.

\section{DAFTAR PUSTAKA}

Aka, R. 2012. Pertumbuhan cempe Peranakan Etawah pascasapih pada pola pemeliharaan sistem kandang kelompok dan kandang individu. Agriplus. 22(2): 96-100.

Ali ,N., N. Munawarah, \& N. Sofyan. 2017. Pengaruh pemberian ampas tahu terhadap produksi air susu dan pertambahan berat badan kambing Peranakan Etawa (PE). Jurnal SAINTEK Peternakan dan Perikanan. 1(1): 23-26.

Bandiati, S., \& K. Prajoga. 2007. Pengaruh silang dalam pada estimasi respon seleksi bobot sapih kambing Peranakan Etawa (PE) dalam populasi terbatas. Jurnal Ilmu Ternak. 7(2): 170-78.

Batubara, A., M. Doloksaribu, \& B. Tiesnamurti. 2014. Potensi Keragaman Sumberdaya Genetik. Prosiding Lokakarya Nasional Pengelolaan dan Perlindungan Sumber Daya Genetik di Indonesia: Manfaat Ekonomi Untuk Mewujudkan Ketahanan Nasional. 206-14.

Demiral, Orkun, M Ün, M. Abay, \& T. Bekyürek. 2007. The effect of artificial insemination timing on the sex ratio of off spring and fertility in dairy cows. Turkish Journal of Veterinary and Animal Sciences. 31(1): 21-24.

Ginting, S. P., \& F. Mahmilia. 2008. Kambing ‘ Boerka ': Kambing tipe pedaging hasil persilangan Boer $X$ Kacang. Wartazoa. 18(3): 115-26.

Haldar, A., P. Prasenjit, M. Datta, R. Paul, S. K. Pal, D. Majumdar, C. K. Biswas, \& S. Pan. 2014. Prolificacy and its relationship with age, body weight, parity, previous litter size and body linear type traits in meattype goats. Asian-Australasian Journal of Animal Sciences. 27(5): 628-34.

Hermesch, S., B. G. Luxford, \& H. U. Graser. 2000. Genetic parameters for lean meat yield, meat quality, reproduction and feed efficiency traits for Australian Pigs 2: Genetic relationships between production, carcase and meat quality traits. Livestock Production Science. 65: 249-59.

Kaunang, D., Suyadi, \& S. Wahjuningsih. 2014. Analisis litter size, bobot lahir dan bobot sapih hasil perkawinan kawin alami dan inseminasi buatan Kambing Boer dan Peranakan Etawah (PE). Jurnal IlmuIlmu Peternakan. 23(3): 41-46.

Kostaman, T., \& I. K. Sutama. 2005. Laju Pertumbuhan kambing anak hasil persilangan antara Kambing Boer dengan Peranakan Etawah pada periode pra sapih. Jurnal Ilmu Ternak dan Veteriner. 10(2): 106-12.

Kostaman, T., and I. K. Sutama. 2006. Korelasi Bobot Badan Induk dengan Lama Bunting, Litter Size, dan Bobot Lahir Anak Kambing Peranakan Etawah. Prosiding Seminar Nasional Teknologi Peternakan dan Veteriner. 522-27.

Kosum, N., T. Taskin, Y. Akbas, \& M. Kaymakci. 2004. Heritability estimates of birth and weaning weights in Saanen, Bornova and Saanen x Kills goats. Pakistan Journal of Biological Science. 7(11): 1963-66.

Mahmalia, F., M. Doloksaribu, \& S. Nasution. 2010. Pengaruh Faktor Non Genetik terhadap Bobot Lahir Kambing Boer pada Stasiun Percobaan Loka Penelitian Kambing Potong Sei Putih." Prosiding Seminar Nasional Teknologi Peternakan dan Veteriner. 477-81.

Mahmalia, F., S. P. Ginting, A. Batubara, M. Doloksaribu, \& A. Tarigan. 2004. Karakteristik Morphologi dan Performans Kambing Gembrong dan Kosta. Prosiding Seminar Nasional Teknologi Peternakan dan Veteriner. 375-80.

Mavrogenis, A. P., A. Constantinou, \& A. Louca. 1984. Production: Environmental and genetic causes of variation in production traits of damascus goats . 1. Pre-Weaning and Post-Weaning. Animal Production. 38: 91-97.

Nasich, M. 2011. Produktivitas kambing hasil persilangan antara pejantan Boer dengan induk lokal (PE) periode pra sapih. Jurnal Ternak Tropika 12(1): 56-62.

Nasution, S., F. Mahmilia, \& M. Doloksaribu . 2010. Pengaruh Musim terhadap Pertumbuhan Kambing Kacang Prasapih 
di Stasiun Percobaan Loka Penelitian Kambing Potong Sei Putih. Seminar Nasional Teknologi Peternakan dan Veteriner 2010: 621-625.

Nurgiartiningsih, V. M. A. 2011. Evaluasi genetik pejantan Boer berdasarkan performans hasil persilangannya dengan kambing lokal. Jurnal Ternak Tropika. 12(1): 8288 ,

Pamungkas, F. A. 2008. Pertumbuhan Anak Kambing Kosta Selama Periode Prasapih pada Induk yang Berumur Lebih dari 4 Tahun. Prosiding Seminar Nasional Teknologi Peternakan dan Veteriner. 378-82.

Prasojo, G., I. Arifiantini, \& K. Mohamad. 2010. Korelasi antara lama kebuntingan, bobot lahir dan jenis kelamin Pedet hasil inseminasi buatan pada Sapi Bali. Veteriner. 11(1): 41-45.

Putri, T. I., \& M. Dewantari. 2017. Peningkatan produktivitas kambing Gembrong yang terancam punah melalui suplementasi multi vitamin-mineral dalam ransum berbasis hijauan lokal. Majalah Ilmiah Peternakan. 20(2): 64-67.

Rasminati, N. 2013. Grade kambing Peranakan Ettawa pada kondisi wilayah yang berbeda. Sains Peternakan. 11(1): 43-48.

Rusdiana, S., and E. Sutedi. 2016. Analisis ekonomi usaha tanaman pangan dan kambing Kosta di Kecamatan Carita Kabupaten Pandeglang, Banten. Buletin Peternakan. 40(3): 228-36.

Setiadi, B., I. K. Sutama, \& I. G. M. Budiarsana. 1997. Efisiensi reproduksi dan produksi kambing Peranakan Etawah pada berbagai tatalaksana perkawinan. Jurnal Ilmu Ternak dan Veteriner. 2(4): 233-36.

Snyman, M. A., J. J. Olivier, G. J. Erasmus, \& J. B. Van Wyk. 1997. Genetic parameter estimates for total weight of lamb weaned in Afrino and Merino Sheep. Livestock Production Science. 48: 0-5.

Sulastri, Sumadi, T. Hartatik, \& N. Ngadiyono. 2014. Performans pertumbuhan kambing Boerawa di Village Breeding Centre, Desa Dadapan, Kecamatan Sumberejo , Kabupaten Tanggamus, Provinsi Lampung. Sains Peternakan. 12(1): 1-9.

Sumardianto, T. A. P., E. Purbowati, \& Masykuri. 2013. Karakteristik karkas kambing
Kacang, kambing Peranakan Ettawa, dan kambing Kejobong jantan pada umur satu tahun. Journal Animal Agriculture. 2 (1): 175-82.

Sutama, I. K. 2011. Inovasi teknologi reproduksi mendukung pengembangan kambing perah lokal. Pengembangan Inovasi Pertanian. 4(3): 231-46.

Sutama, I. K, I. G. M Budiarsana, I. W. Mathius, \& E Juarini. 1999. Pertumbuhan dan perkembangan seksual anak kambing Peranakan Etawah dari induk dengan tingkat produksi susu yang berbeda. Jurnal Ilmu Ternak dan Veteriner. 4(2): 95-100.

Suyasa, N., P. Ida, \& E. Siti. 2016. Potensi dan Keragaman Karakter Kambing Kacang , Peranakan Ettawa ( PE ) dan Gembrong di Bali. Prosiding Seminar Nasional Inovasi Teknologi Pertanian. 1359-66.

Yulistiani, D., I. W. Mathius, I. K. Sutama, U. Adiati, R. S. G. Sianturi, Hastono, \& I. G. M. Budiarsana. 1999. Respon produksi kambing PE induk sebagai akibat perbaikan pemberian pakan pada fase bunting tua dan laktasi. Jurnal Ilmu Ternak dan Veteriner. 4(2): 88-95.

Yunanda, Sulastri, \& M. Hamdani. 2013. Seleksi induk kambing Peranakan Etawah berdasarkan nilai most probable producing ability bobot sapih di Kelompok Tani Margarini. Jurnal Ilmiah Peternakan Terpadu. 1(3): 22-25. 